\section{China launches genome project}

Beijing. The National Natural Science Foundation of China (NSFC), the country's main funding agency for basic research, has launched a national human genome project as part of its contribution to international efforts to sequence the human genome.

The decision to link up with sequencing efforts in other countries represents a determination by China's science policy -makers that the country should not be left behind in major frontier research fields. Zhou GuangZhao, president of the Chinese Academy of Sciences, has said that China's ambition is to win "gold medals" in what he describes as the "World Science Olympics".

China's participation in the human genome project could be significant. "The Chinese account for over one-fifth of the world's population, and the country has 56 ethnic groups," says one NSFC official. "As a result, no databank of human genetic information can be said to be complete without a detailed study of the Chinese human genome."

The project is likely to have important practical implications, as the Chinese are expected to contribute vital information that may lead to the early diagnosis and treatment of more than 5,000 hereditary diseases.

NSFC has not yet revealed how much money it is making available for genome

sequencing. However, it has already outlined a number of goals, including the collection and storage of the genomes of ten selected Chinese ethnic groups, and focusing on the genes that induce diseases peculiar to these groups.

Earlier this year, China announced that it was launching a programme to sequence the rice genome. The headquarters of the project is located in the life sciences research institute of the Shanghai branch of the Chinese Academy of Sciences.

Five satellite research centres have now been established in different parts of the country. Rice is China's staple food, and the Chinese rice genome project, described as second only to the world human genome programme, is intended to help produce improved rice varieties.

Jiang Ze-Min, state president of China and general-secretary of the Chinese Communist Party Central Committee, has pledged support for basic research in the country. Jiang, who is also president of the Chinese Central Military Commission and is a former minister for the electronics industry, made his remarks during a meeting on 12 August with the Nobel prize winners Gerd Binnig and Heinrich Rohrer, who were attending a conference on scanningtunnelling microscopy held in the Chinese capital.

You Qin 4

\section{Satellite disappearance remains a mystery}

Beijing. A joint China-US enquiry into the disappearance of an Australian communication satellite, Optus B2, launched on a Chinese rocket in December, formally ended last month with a joint communique in which each side acknowledges the claim of the other that it was not to blame.

The \$138-million satellite was built by Hughes Space and Communications of the United States, but owned by an Australian company, Optus Communications. It was launched on 21 December last year by a Chinese Long March 2E rocket from the Xichang Satellite Launch centre in southwestern China's Sichuan province. Approximately 48 seconds into the flight, there was an explosion on the spacecraft and the satellite disappeared from the monitor screen for reasons that have never been explained.

The latest joint communique suggests that the disappearance is likely to remain a mystery. It maintains that "the Chinese side finds no evidence that any flaw in the rocket has caused the failure and Hughes accepts this". But it also says that "Hughes finds no flaw in the manufacturing of the satellite has caused the failure and the Chinese side accepts this."

Both sides have agreed to conclude the enquiry, and to work together on launching another Optus satellite in the first half of
1994. To reduce the chances of similar incidents in future, Hughes and the China Great Wall Industrial Corporation (the Chinese contractor) have promised to make design improvements to the satellite and the rocket respectively.

The failure of Optus B2 seems to have had little effect on China's bidding to launch commercial satellites. The country has secured a significant share of the 66 satellite launches that are to be provided for the US Motorola Company between 1996 and 2002. It has also won contracts to launch three satellites for overseas companies in the next two years.

YQL
Beljing. China has formally enacted a nuclear accident law detailing the emergency measures to be carried out in case of an accident at a nuclear power plant. The decree, which was issued last month by Premier Li Peng, is the first of its kind in China, and is intended to provide guidance to the authorities on how to deal with possible nuclear accidents.

The law includes provisions covering the imposition of a state of emergency, the release of information and the operation of rescue work. It applies to any incident re-

\title{
Science gets the vote, but who was Einstein?
}

Beijing. A national survey carried out by the China Association of Science and Technology has shown that scientists and engineers enjoy high prestige among the public. Half of those surveyed said they would like their children to study science and engineering subjects at university, and subsequently to become scientists.

The survey was based on the results of interviews carried out over the past

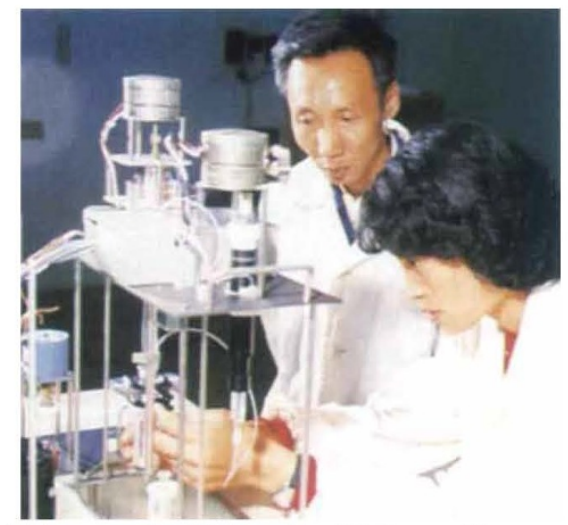

Chinese scientists enjoy high prestige among the population.

year with 4,200 people between the ages of 16 to 69 . Asked whether they considered that science and technology played an active role in achieving social progress, the majority of the interviewees said they agreed.

But such high expectations contrast with the low level of scientific understanding also revealed by the survey. Almost 20 per cent had no idea whether the Sun revolves around the Earth or vice versa. Fewer than half knew that it takes one year for the Earth to revolve around the Sun. And most had never heard of Albert Einstein.

On one point, the Chinese scored much higher than those in a comparable survey in the United States: 70 per cent said that they accepted Darwin's theory of evolution, compared with a US figure of 45 per cent. At the same time, however, nearly half of the Chinese believers thought that human beings existed at the time of dinosaurs. YQL

\section{Nuclear accident law is passed}

sulting in the leak of radioactive materials into the atmosphere.

At present China has one nuclear plant in operation, the Qinshan nuclear power station, located just south of the country's largest industrial city, Shanghai. The country's second plant, in south China's Guangdung province, is expected to be completed next year. Its proximity to Hong Kong has given rise to public concern over safety which reached a climax during the 1989 student protest. But protests against nuclear power have since declined. YQL 